\title{
Index Vol. 19, 1988
}

\begin{tabular}{|c|c|c|c|c|c|c|c|c|c|c|}
\hline No. & 1 & 2 & 3 & 4 & 5 & 6 & $7 / 8$ & 9 & 10 & $11 / 12$ \\
\hline Month & January & February & March & April & May & June & July/Aug. & September & October & Nov./Dec. \\
\hline Issue & Physics & Computers & Meetings & Physics & Physics & $\begin{array}{l}\text { Physics } \\
\text { +Directory }\end{array}$ & Physics & Physics & Meetings & Physics \\
\hline Pages & $1-16$ & $17-32$ & $33-40$ & $41-56$ & $57-72$ & $73-88$ & $89-104$ & $105-120$ & $121-128$ & $129-144$ \\
\hline
\end{tabular}

Applied Physics, Physics in Industry Advisory Committee, 58, 80

Hydrogen-metal interaction, 65-67

Industrial Workshops, 16, 102, 103, 123-127

Lasers, FIR for current profile measurement, 8-10 semiconductor, 1-4

instabilities and chaos in, 84-88

Simulated annealing for system

optimization, 14-16

Astronomy and Astrophysics

Accretion disks and magnetic fields, 142

European very large telescope, 99-102

Division, report to Council, 59

and Section Boards, 81

Very long baseline interferometry, 46-52

Atomic and Molecular Physics

Division, report to Council, 59

and Section Boards, 72, 81

Single-atom oscillators, $105-108$

Trapping neutral atoms with EM fields, 68-72

Balkan Physical Union, 60

Chaos, in Josephson junctions and SQUIDS, 53-55 and instabilities in lasers, 84-88

Computers, special issue

Artificial intelligence, 31-32

Computation-intensive calculation

techniques, 21-22

Computer algebra, 28-30

Control systems, 22-23

Personal computing, 17-19

Simulations of pattern formation, 24-27

Trends in supercomputers, 19-20

Condensed Matter Physics

Aharonov-Bohm effect in normal metals, 89-93

Chaos in Josephson junctions and SQUIDS, 53-55

Division, report to Council, 60 and Section Boards, 81

High $T_{\mathrm{c}}$ superconductivity, prizes of, 5-7

study by neutron powder difraction, 73-76

Hydrogen-metal interaction, 65-67

Ice, physics of, 61-64

Magnetic metals, 41-45

Semiconductor lasers, 1-4

Simulated annealing for spin-glass-like problems, 13-16

Surface crystallography by $\mathrm{X}$-ray diffraction, 94-98

$\begin{array}{ll}\text { Authors } & \text { J. Calmet, 28-30 } \\ \text { G. Belvedere, 142 } & \text { A. Cheetham, 115-118 } \\ \text { J.L. Bobin, 137-141 } & \text { D. Dalibard, 68-72 } \\ \text { Y. Bruynseraede, } & \text { R. Feidenhans' } 1 \text { ' 94-98 } \\ \text { 89-93 } & \text { F. Grey, 94-98 } \\ \text { J. Buus, 1-4 } & \text { R. Gruber, 17, 19-20 }\end{array}$

EPS Divisions, Sections and Group Astronomy and Astrophysics Division

Solar Physics Section
Atomic and Molecular Physics Division Atomic Spectroscopy Section Chemical Physics Electronic and Atomic Collisions Molecular Physics
Computational Physics Group

Condensed Matter Division Liquids Section

Low Temperature Physics Section

Macromolecular Physics

Magnetism

Metal Physics

Semiconductors and Insulators

Surfaces and Interfaces

High Energy \& Particle Physics Division

Interdiv. Group on Exptl. Phys. Control Systems

Interdiv. Group on Physics for Development

Nuclear Physics Division

Optics Division

Plasma Physics Division

Quantum Electronics Division

\section{Principal Subjects}

Conferences, 33-40, 121-128

Advisory Committee, 58, 80

Education

Advisory Committee, 58-59, 80

History of physics group, 104

Physics and mathematics, 109

European Physical Society

Advisory Committees, 80

Anniversary Seminar, 55, 110-112

Associate Members, 79

Collaborating Societies, 78

Council, report from Dresden, 58-60

Delegates to Council, 77-78

of IOMs, appeal, 30, 59, 112-114

Division and Section Boards, 81-82

Editorial Boards, 83

Executive Committee, 56, 77

reply, 114

Industrial Workshops, 16, 123-127

magneto-optical recording report, 102

SQUID report, 103

Members, 16, 56, 77-78, 98, 143

Presidential message, 57

Unit fee, 58

Zagreb seminar, 143

Hewlett-Packard Europhysics Prize

Call for nominations, 64

1988, K.A. Müller and J.G. Bednorz, 5-7

High Energy and Particle Physics

Acceleration techniques in future, 137-141

Division, report to Council, 59-60

Board, 81

EMC effect: quarks and gluons shared, 129-132

Infrared, far, detection, 11-13

asers for plasma current measurement, 8-10

Inter-Divisional Groups

Computational Physics, Board, 32

message from Chairman, 17

Experimental Physics Control Systems,

endorsement, 60

inaugural conference, 22-23

officers, 83

Physics for Development, Board, 82

C. Van Haesendonck, 89-93

R.G. Harrison, 84-88

A.W. Hewat, 73-76

B. Humpert, 31-32

F. James, 21-22

J. Kertesz, 24-27
M. Kimmitt, 11-13

W.O. Lock, 119-120

A.R. Mackintosh, $41-45$

I. Morgenstern, 14-16

W.S. Newman, 109

J.K. Norskov, 65-67

Y.A. Ossipyan, 61-64
Japan, Physical Society of, 118

Laplacian pattern formation, 24-27

Magnetism, magnetic metals, 41-45

Neutron powder diffraction, 73-76

Nobel Prize

1987, K.A. Müller and J.G. Bednorz

Prizes of high $T_{\mathrm{c}}$ superconductivity, 5-7

1988 , L. Lederman, M. Schwartz,

J. Steinberger, 143

Lindau meeting, 109

Nuclear Physics

Division, report to Council, 60

Board, 81

Ultra relativistic heavy ion research, 133-136

Optics

Elections to Board, 30, 81

Physics and Society, Advisory Committee, 59, 80

Plasma Physics,

Conference exhibit, 104

Division, report to Council, 59 Board, 81

Publications

Advisory Committee, 80

Editorial Boards, 83

EPS Recognised journals, 83

Europhysics Conference Abstracts, 79

Europysics Letters, 60, 83

Europhysics News, 59, 83, 113-114

Quantum Electronics

Board, 72, 82

Who's Who, 60

Schools, 33-40, 121-128

E-W high energy physics, $119-120$

Standards, SUN revision, 104

Thermonuclear fusion

Current profile measurement in Textor, 8-10

Pellet fuelling of tokamaks, 115-118

N.F. Pedersen, 53-56

V.F. Petrenko, 61-64

P.B. Renton, 129-132

R.A. Ricci, 57

C. Salomon, 68-72

R. Santo, 133-136

R.T. Schilizzi, 46-52
H. Soltwisch, 8-10 J.S. Uppal, 84-88

T. Vicsek, 24-27

H. Walther, 105-108

I. Willers, $17-19$
Europhysics News is the official journal of the European Physical Society which comprises 29 National Socie ties, Academies and Group, about 4000 Individual Members and 75 Associate Members. Governing bodies of EPS are the General Meeting, Council and an dies of EPS are the General Meeting, Council and an elected Executive Committee responsible for detailed policy. EPS promotes the collaboration of physicists throughout Europe, organising and harmonising conferences and publications, improving physics education, encouraging physics applications, awarding scholarships to sponsored schools in Erice. EPS publishes in ships to sponsored schools in Erice. EPS publishes in
addition to Europhys. News, Europhysics Letters (in partnership with national societies), European Journal of Physics (in partnership with The UK Inst. of Phys.) and European Conference Abstracts. Individual Members receive Europhys. News free of charge (price to insts: Sw.Fr. 90.-/a), Europhys. Lett. at Sw.Fr. 125.-/a insts: Sw.Fr. 90.--a), Europhys. Lett. at SW.Fr. 125.-la
(insts. 1050.-), rebates on many other publications and (insts. 1050.-), rebates on many other publications and on conference fees. From Jan. 1989, membership fee society is: Sw.Fr. 48--aa; independent mbrs: Sw.Fr. 144.-la; mbrs of a Collaborating Society: Sw.Fr. 60--/a.

\section{Editor: E.N. Shaw}

Editorial Board:

A. Baratoff, F. James, M. Lehmann,

M. Mayor, J. Muller, M. Siegrist

Editorial and Advertising Office at the EPS Secretariat

Address: EUROPEAN PHYSICAL SOCIETY P.O. Box 69 , CH-1213 Petit-Lancy 2

Switzerland

Telephone: Geneva (22) 931130

Telex : 428024 eps ch

Telefax: (22) 931317

Printed by: Pfirter frères sa

CH-1213 Petit-Lancy/Switzerland 